\title{
Povratne umirovljeničke migracije na hrvatskim otocima
}

DOI: $10.11567 /$ met.29.2.4.

UDK: 314.745.3-054.75-057.75(497.5)(210-7)

Prethodno priopćenje

Primljeno: 17.10.2013.

Prihvaćeno: 28.11.2013.

\author{
Mario Bara \\ Institut za migracije i narodnosti, Zagreb \\ mario.bara@imin.hr
}

\begin{abstract}
SAŽETAK
Iseljavanje i depopulacija na većini hrvatskih otoka kontinuirano traju desetljećima, što je odredilo njihov demografski i društveno-gospodarski razvoj. Za mnoge je iseljenike povratak kući mogućnost o kojoj razmišljaju tijekom života. Premda povratnički tokovi donekle mogu ublažiti dugotrajne negativne demografske trendove, dominantni su oblik povratnih migracija na hrvatskim otocima, napose malima, povratne umirovljeničke migracije. Time se povećava udio staroga u ukupnome stanovništvu i samo se prividno ublažavaju posljedice dugotrajne emigracije. Tri su temeljna pojma kojima se rad bavi: umirovljenje, povratna migracija i reintegracija u lokalne otočne zajednice. Autor ih potkrepljuje podacima istraživanja prikupljenima metodom intervjua s povratnicima umirovljenicima na četiri hrvatska otoka (Lošinj, Zlarin, Kaprije i Žirje). Povratak se kroz model životnog toka promatra kao jedna od etapa u migracijskom procesu, koji ne mora biti konačan, a može biti potencijalno reverzibilni korak.
\end{abstract}

KLJUČNE RIJEČI: umirovljenje, povratne migracije, reintegracija, hrvatski otoci

\section{UVOD}

Demografska, socijalna i razvojna perspektiva hrvatskih otoka u znatnoj su mjeri određene položajem ovisnosti i rubnosti u odnosu na kopno. Razlike u njihovoj veličini i naseljenosti, položaju i prometnoj povezanosti značajne su za kvalitetu i organizaciju načina života stanovništva. Migracija je važan čimbenik u životu pripadnika otočnih zajednica, često i kao nužnost opstanka iseljenika i članova obitelji koji ostaju na otocima, uglavnom iz ekonomskih razloga. Velikim promjenama u migracijskim strujanjima, kao posljedica niza ekonomskih, socijalnih i političkih zbivanja, krajem 19. i kroz 20. stoljeće otoci postaju dominantno emigracijska područja, što 
će uvelike utjecati na njihov demografski i društveno-gospodarski razvoj (Podgorelec i Klempić Bogadi, 2013). U drugoj polovini 20. stoljeća uz prekomorsku emigraciju jača iseljavanje u kopnena urbana središta, u bliža obalna Split, Rijeku, Zadar i Šibenik, ali i udaljenija u unutrašnjosti te u Zagreb kao najveće urbano i gospodarsko središte u Hrvatskoj. Na većini hrvatskih otoka traje višedesetljetno iseljavanje radno aktivnog stanovništva, primarno zbog nemogućnosti zapošljavanja na otocima, ali i zbog spoznaje da kopnena urbana središta pružaju veće mogućnosti te omogućuju individualizaciju životnih stilova i višu kvalitetu života. Depopulacija otočnog stanovništva odvijala se u skladu s općim prilikama u zemlji u kojima se težište društveno-gospodarskog razvoja premještalo u urbano-industrijska središta u razdoblju najintenzivnije industrijalizacije i ruralnog egzodusa u Hrvatskoj (Faričić, Graovac i Čuka, 2010: 155). Višedesetljetna, nerijetko i stoljetna, emigracija ima za posljedicu da gotovo ne postoji otočna obitelj u kojoj barem jedan član nije proveo duže razdoblje svoga života izvan otoka, zbog obrazovanja, zaposlenja ili nekog drugog razloga.

Gospodarski depresivne regije poput hrvatskih otoka imaju zbog nemogućnosti zapošljavanja, visoke stope nezaposlenosti i niskih infrastrukturnih ulaganja manju vjerojatnost za povratne migracije u radno aktivnoj dobi (Faričić, Graovac i Čuka, 2010; Podgorelec i Klempić Bogadi, 2013). Osim toga su dugogodišnja istraživanja otočnih zajednica (Babić, Lajić i Podgorelec, 2004; Podgorelec, 2008, 2010; Podgorelec i Klempić Bogadi, 2013) potvrdila da niska razina ekonomskih aktivnosti na otocima većini iseljenih ostavlja mogućnost povratka tek nakon završetka radne dobi i osiguravanja mirovine kao glavnog prihoda.

$\mathrm{U}$ istraživanju čiji su rezultati prezentirani u ovome radu nastojali smo integrirati povratne i umirovljeničke migracije s konceptom socijalne integracije u zatvorenim zajednicama te iznijeti problematiku socijalne stvarnosti na otocima. Namjera nam je razviti dublje razumijevanje povratnih migracija u kontekstu hrvatskih otoka, istaknuti moguća ograničenja u reintegraciji te opisati suvremene prakse života na otocima, koje se na malim otocima sve češće manifestiraju sezonskom naseljenošću.

\section{METODOLOGIJA ISTRAŽIVANJA}

U radu se raspravlja o tri temeljna pojma: umirovljenju, povratnoj migraciji i reintegraciji u lokalne otočne zajednice. Ciljevi su rada istražiti: a) motive za povratak, b) pitanja reintegracije u otočne zajednice i c) stalnost povratka. Uz analizu literature upotrijebit ćemo i dio podataka prikupljenih 
istraživanjem provedenim na četiri hrvatska otoka: Lošinju, Zlarinu, Kaprijama i Žirju. Otoci su izabrani prema razlikama s obzirom na veličinu, brojnost stanovništva, stupanj razvijenosti, udaljenost od kopna i kvalitetu povezanosti s najbližim obalnim središtem. Šibenski otoci, prema kriteriju broja stanovnika, pripadaju malim otocima s nerazvijenom ekonomijom koji imaju karakteristike ruralnih prostora. Za razliku od njih drugačiji je razvoj imao Lošinj, koji ima dugu tradiciju turizma, brodogradnje i naseljavanja te je jedini otok među navedenima koji ima veće gradsko naselje - Mali Lošinj.

Kvalitativna metodologija u ovom je istraživanju prije svega odabrana zbog specifičnosti ciljane populacije (umirovljenika povratnika). Upotrebu metode ankete $u$ svome smo istraživanju smatrali nepraktičnom jer ne postoje precizni podaci o brojnosti i karakteristikama umirovljenika povratnika, uz što se veže problem »fiktivnog stanovništva«, pa ne bi imala statističku relevantnost (Lajić i Mišetić, 2005; Mišetić, 2006). Najnovije istraživanje na šibenskim otocima (Podgorelec i Klempić Bogadi, 2013: 35) dokazuje da je na nekim otocima registrirani broj stanovnika i do trideset posto veći od stvarnog broja stalnog stanovništva.

Dodatni je razlog odabira kvalitativne metodologije istraživanje onih pitanja koja ne bi bilo moguće potpuno obuhvatiti metodom ankete jer se pojedina životna iskustva ispitanika ne mogu predvidjeti pitanjima u upitniku.

Provedba istraživanja. Istraživanje je provedeno metodom intervjua. Upotrijebili smo polustrukturirane intervjue sa zadanim okvirnim temama razgovora bez propisanog redoslijeda pitanja i striktnog protokola. Uzorak istraživanja bio je namjerni, a ispitanici su birani metodom »snježne grude«. Intervjuiranje je provedeno $\mathrm{u}$ nekoliko etapa. ${ }^{1}$ Prije provedbe intervjua $\mathrm{s}$ povratnicima umirovljenicima, provedena su dva ekspertna intervjua, jedan za šibenske otoke i jedan za otok Lošinj. Ekspertni intervjui provedeni su s mjesnim političkim i društveno-kulturnim predstavnicima. Eksperti su imali odlučujuću ulogu u inicijalnoj etapi istraživanja u pristupu (usp. Seidman, 2006: 45) potencijalnim sugovornicima za nastavak istraživanja. Odabrani su na osnovi informacija koje su nam proslijedili drugi istraživači koji su istraživali otočne zajednice.

Na Kaprijama i Žirju intervjui su provedeni u lipnju 2011., na Zlarinu u studenome 2011., a na Lošinju u svibnju 2013. Ukupno je provedeno jedanaest intervjua sa šest žena i pet muškaraca različite dobi. Raspon dobi ispita-

Istraživanje je provedeno u sklopu projekta MZOŠ-a Utjecaj migracija na regionalni razvoj Hrvatske (076-0762385-2375) voditelja dr. sc. Ivana Lajića. 
nika kretao se od 59 do 91 godine. Tri su intervjua provedena na Zlarinu, tri na Kaprijama, dva na Žirju i tri na Lošinju. Ispitanici su prethodno bili upoznati s temom istraživanja, povjerljivošću postupka, jamstvom anonimnosti i dobrovoljnoj osnovi sudjelovanja u istraživanju. Bili smo maksimalno fleksibilni u izboru lokacije i vremena provedbe intervjua. Ispitanici su intervjuirani u svojim domovima, a unutar pojedinoga kućanstva intervjuirana je samo jedna osoba. Između ostaloga, teme o kojima se razgovaralo bile su umirovljenje, motivi povratne migracije i problemi vezani uz reintegraciju u lokalnu otočnu zajednicu. Pitanja su bila otvorenog tipa, čime se ispitanicima omogućio razgovor o svim problemima. U raspravi ćemo pri atribuciji pojedinih citata sugovornika upotrebljavati sljedeće kratice: $\mathrm{M}$ - muški, Ž - ženski označuju spol sugovornika te E - ekspertni intervju, čemu se pridodaje dob. Razgovor je sniman tonski, a citati će biti upotrijebljeni doslovno kako su ispitanici odgovarali, na standardom jeziku ili dijalektu, kako su i bilježeni. ${ }^{2}$ Bilježena su i ponavljanja, stanke i drugi izražajni oblici poput usklika ili smijeha ako se smatralo da utječu na sadržaj intervjua. Iz citata su u nekim slučajevima izbrisana imena i specifični toponimi kako bi se dodatno zaštitio identitet sugovornika.

\section{UMIROVLJENJE}

Koncept umirovljenja odnosi se na više različitih pojava i procesa. Umirovljenje kao institucija obuhvaća društvene strukture koje reguliraju povlačenje starijih radnika s tržišta rada i pruža mirovinsko osiguranje onima koji ga napuste pod određenim uvjetima. Kao proces odlazak u mirovinu implicira odluke i obrasce povlačenja s tržišta rada. Iskustvo mirovine odnosi se na mnoštvo životnih promjena koje donosi razdoblje nakon prestanka radne uloge. Ti su fenomeni usko povezani i s drugim društvenim strukturama i sferama života. Za raspravu o umirovljenju iznimno je važno kako društvo promatra dob i starenje. Ono što društvo procjenjuje prikladnim i što očekuje od određenih dobnih skupina stanovništva ima duboke kulturne implikacije (Phillipson, 1998). Promatrajući iz ekonomske perspektive,

2 Pripadnost otočnoj zajednici često se očituje u upotrebi dijalekta. Tijekom istraživanja na otocima Zlarinu, Kaprijama, Žirju i Lošinju primijetili smo da su ispitanici na Žirju i Kaprijama, podjednako oni koji su radni vijek proveli u obližnjim obalnim središtima i oni koji su živjeli u prekooceanskim zemljama, upotrebljavali mjesne idiome, za razliku od povratnika na ostalim otocima, koji su se služili standardnim jezikom ili su svoj govor prilagođavali istraživaču. Te razlike dijelom možemo objasniti dobi ispitanika, koji su nešto stariji na Kaprijama i Žirju od onih na drugim otocima te su najraniju mladost proveli na otoku u razdoblju kad sociokulturni utjecaji s kopna još nisu bili toliko jaki i većom relativnom izoliranošću tih dvaju otoka u odnosu na druge. 
umirovljenje je uglavnom definirano kao događaj napuštanja razdoblja zaposlenosti u životnom toku pojedinca i početak služenja umirovljeničkim beneficijama. Definirana s aspekta sudjelovanja na tržištu rada, mirovina je trenutak u kojem pojedinac prestaje raditi za plaću - "potpuno i trajno povlačenje iz plaćenog rada « (Costa, 1998: 6). Drugi argumenti pri određivanju statusa umirovljenika odnose se na visinu socijalnih naknada. Osim toga važni aspekt umirovljenja određuje pojedinac osobno - prihvaćajući ili ne prihvaćajući ulogu umirovljenika. Umirovljenje se može definirati i kao promjena uloga ili identiteta. Društvo projicira što je prihvatljivo za neku dob u kojoj pojedinac mijenja uloge, odričući se starih uz usvajanje novih s kojima se dobivaju neka prava i dužnosti. »Proces umirovljenja uključuje razdvajanje pojedinca od uloge zaposlenika, koji radi za plaću, i stjecanje uloge umirovljene osobe « (Atchley, 1976: 139). U tom procesu institucije imaju važnu ulogu. Projicirane uloge uz dobne norme mogu biti formalno iskazane kroz socijalne politike i zakone, poput zakonom predviđene dobi za umirovljenje (Hooyman i Kiyak, 2008). Sukladno tome status neke osobe može varirati, ovisno o brojnim objektivnim i subjektivnim čimbenicima.

Umirovljenje kao institucija formalno se oblikovalo u industrijaliziranim zemljama krajem 19. i početkom 20. stoljeća, a razvijalo se i postalo globalno rašireno nakon Drugoga svjetskog rata (Williamson i Pampel, 1993). Danas se razdoblje mirovine smatra uobičajenim dijelom života u većini zapadnih društava. Institucije se mogu definirati kao uspostavljeni obrasci koji su podržani normama i sankcijama te su ponekad obilježene inicijacijskim ritualima. Institucija umirovljenja obuhvaća različite normativno prihvaćene obrasce povlačenja s tržišta rada. Sankcije se javljaju uglavnom putem financijskih destimulacija, ali mogu uključivati i društveni pritisak. Rituali inicijacije ograničeni su i usredotočuju se više na umirovljenikova postignuća tijekom radnog razdoblja nego na umirovljenički identitet (Szinovacz, 2003: 7).

Različiti čimbenici utječu na pojedinčevo iskustvo umirovljenja i na prilagodbu umirovljenju. Najupečatljivija činjenica koja se mora uzeti u obzir jest promjena životnih obveza u starijoj dobi. Umirovljenje formalno oslobađa pojedinca od radnih obveza i ostavlja mu na raspolaganju znatno više slobodnog vremena, koje može ispuniti na različite načine. Jedna od mogućih tranzicija u tome razdoblju jest migracija, a među umirovljenim migrantima to je često povratna migracija u mjesto iz kojeg su krenuli u emigraciju. 


\section{POVRATNE MIGRACIJE}

Iako su povratne migracije jedna od važnih komponenti migracijskih tokova, dugo su bile među manje istraživanim fenomenima. Većina autora više se bavila demografskim i pravnim aspektima vraćanja imigranata, problemima imigracijske politike zemalja primitka i zemalja podrijetla migranata, zakonskim rješenjima te analizom troškova (Peračković, 2006: 479). Jedan od razloga koji su utjecali na rjeđe istraživanje povratnih migracija može se naći i u nedostatku pouzdanih statističkih podataka koji bi mogli pomoći u objašnjavanju i praćenju tog fenomena. Često se migracijama pristupalo kao jednosmjernom procesu koji najčešće počinje u ruralnoj i završava u urbanoj sredini. Prije većeg usmjeravanja interesa znanstvenikâ na povratne migracije prevladavala su tri dominantna pravca u migracijskim istraživanjima: a) studije inicijalne migracijske odluke, b) studije adaptacije, akulturacije, integracije i interakcije imigranata u društvima primitka i c) studije čiji je fokus bio na izravnim posljedicama emigracije na društva podrijetla, bez utjecaja povratnih migracija (King, 1986: 2). Istraživanja unutar triju pravaca rijetko su uzimala u obzir i povratne migracije kao dio šire cjeline.

Povratak vanjskih migranata u zemlju podrijetla uglavnom se definira kao »proces zatvaranja migracijskog ciklusa vraćanjem vanjskih migranata u izvorno emigracijsko društvo « (Nejašmić, 1981: 10). Prema definiciji Statističkog odjela Ujedinjenih naroda za prikupljanje podataka o međunarodnoj migraciji, povratnici su »osobe koje se vraćaju u zemlju svoga državljanstva nakon što su bile međunarodni migranti (bilo kratkoročno, bilo dugoročno) $\mathrm{u}$ drugoj zemlji, a koje namjeravaju ostati u zemlji podrijetla najmanje godinu dana « (Dumont i Spielvogel, 2008: 164). ${ }^{3}$ Naglašavajući njegovu sociološku dimenziju, Krešimir Peračković definira povratak kao »sveukupnost povratnikovih doživljaja stečenih u procesu povratka i reintegracije u staru sredinu « (2006: 491). Dakle riječ je o jednoj etapi u migracijskom procesu koja nije jednosmjerna i ne mora biti konačna, a može uključivati proces planiranja, posjećivanje i druge načine informiranja o realnosti povratka te potom reintegraciju u lokalnu sredinu. Odluka o povratku može biti slože-

Definicija obuhvaća četiri dimenzije: a) zemlju podrijetla, b) stanovanje $u$ inozemstvu, c) duljinu boravka u zemlji domaćinu i d) duljinu boravka u domovini nakon povratka. Prema toj definiciji, domovina migranta odnosi se na njegovo državljanstvo. No za osobe rođene $\mathrm{u}$ inozemstvu koje su naturalizirane (druga i sljedeće generacije iseljenika) definicija koja se temelji isključivo na zemlji državljanstva ne čini se prikladnom. Razlike u zakonodavstvu o državljanstvu otežavaju međunarodnu usporedivost. Boljim rješenjem za definiranje povratnika čini se da se zemlja rođenja uzme kao kriterij za identificiranje povratne migracije (Dumont i Spielvogel, 2008: 164). 
na zbog niza čimbenika (zaposlenost partnera, ovisnost djece i dr.), a može biti povezana s ekonomskim prilikama u zemlji/regiji podrijetla i prebivanja. Na odluku o povratku mogu utjecati duljina boravka, količina ušteđevine te zadovoljstvo trenutačnom ulogom i statusom pojedinca. Nadalje, ne treba zanemariti ni druge čimbenike koji se razmatraju prilikom donošenja migracijske odluke, a ne javljaju se samo u umirovljeničkim povratničkim tokovima već i u migracijama potaknutima ugodnošću, zdravstvenim potrebama, potrošnjom i sl. Primjerice velika urbana središta mogu biti prenapučena, niže razine sigurnosti, lošijega zdravstvenog okoliša i preskupa za visoku kvalitetu života u mirovini, pa se mjesto podrijetla može činiti idealnim izborom za život u kasnijoj dobi.

Francesco Cerase (1974) pokazao je na osnovi studije povratnih migracija Talijana iz SAD-a koliko može biti kompleksna veza između povratničkih očekivanja te društvenoga i ekonomskoga konteksta u zemlji ili regiji podrijetla. On je identificirao četiri tipa povratnika, ističući njihove aspiracije, očekivanja i potrebe:

- povratak zbog neuspjeha odnosi se na one povratnike koji se nisu integrirali u zemljama primitka zbog predrasuda i stereotipa s kojima su se susretali;

- povratak zbog »konzervativizma« uključuje one migrante koji su prije emigracije planirali povratak kući s dovoljno ušteđevine kako bi se oslobodili ekonomske ovisnosti;

- umirovljenički povratak odnosi se na umirovljene migrante koji se odlučuju za povratak u zemlje podrijetla i, ako ih već ne posjeduju, stjecanje zemlje i kuće u mjestima gdje planiraju provesti starost. Kao distinkcija u odnosu na druge kategorije povratnika ističe se njihova percepcija da povratak predstavlja novo razdoblje života koje je i početak posljednje etape u njihovu životnom toku. Nadalje, ta skupina ima pozitivniji odnos prema povratku nego ostale kategorije povratnika (Cerase, 1974: 257-258);

- povratak zbog inovacije odnosi se na one povratnike koji su stekli određena znanja i vještine i spremni su ih upotrijebiti u zemljama podrijetla (Cerase, 1974: 258).

Najveći dio migranata od početka odluke o migriranju ne želi i ne namjerava trajno ostati u zemlji primitka (Reyes, 1997). Za mnoge je migrante ideja povratka kući mogućnost koja se održava tijekom životnog toka. Veze s domovinom i/ili mjestom podrijetla, čak i ako su slabijeg intenziteta, odr- 
žavaju težnju za povratkom. Neki će se vratiti u mjesta podrijetla, drugi neće, neki će se odseliti u novo odredište, a drugi će biti uhvaćeni u ciklus kružne migracije. Povratak je jedna od mogućih etapa u migracijskom procesu i životnom toku pojedinca. Povratna migracija ne mora nužno biti jednosmjerna ni konačna, a uključuje planiranje i posjete odredištu podrijetla te po povratku zahtijeva prilagodbu.

\section{UMIROVLJENIČKE MIGRACIJE}

Definiranje umirovljeničkih migracija složeno je iz više razloga. Primjerice ne mogu se objasniti pomoću klasičnih teorijskih koncepata, prema kojima su migracije definirane ekonomskim razlozima. To znači da se konceptualni modeli temeljeni na radnom odnosu ne mogu primijeniti na migracije u kasnijoj životnoj dobi, uključujući i razdoblje umirovljenja. Suvremene društvene promjene proizvode nove životne stilove koji čine klasične definicije migracija zastarjelima. Tradicionalne definicije razlikuju umirovljeničke od drugih migracija koristeći se dobnim kriterijem - zakonom propisanom dobi za umirovljenje, odnosno radnim ili umirovljeničkim statusom osobe (Haas i sur., 2006). Umirovljeničke migracije obično se kratko i nedovoljno precizno definiraju kao migracije umirovljenikâ. Iako analitički prikladno, takvo je objašnjenje nejasno jer uključuje migraciju u trenutku umirovljenja kao i migracije tijekom životnog razdoblja u mirovini. Definiranje umirovljeničke migracije isključivo na temelju tradicionalne dobi umirovljenja pretpostavlja da je migracija potaknuta velikom tranzicijom u životu i da se javlja u vrijeme umirovljenja ili u razdoblju od nekoliko godina nakon umirovljenja (Wiseman, 1980; Litwak i Longino, 1987).

U razmatranju i sintezi literature o umirovljeničkim migracijama važno je istaknuti da se pojam odnosi na razne migracijske procese koji se odvijaju u različitim prostornim, političkim, društvenim i ekonomskim kontekstima. Naime ne postoji akademski konsenzus o tome koje sve fenomene pojam uključuje i kako ga teorijski definirati. Zbog nepostojanja jasnih i čvrstih međusobnih granica u navedenim oblicima migracija odlučili smo se u radu koristiti širokim pojmom umirovljeničke migracije koji obuhvaća i neke migracijske prakse uključene u razne druge teorijske koncepte. Budući da postoji snažna veza između stopa migracija i početnih faza umirovljenja, ograničit ćemo se na kriterij umirovljenja i osiguravanje mirovine kao primarnog izvora prihoda, koji omogućuju pokretanje povratne migracije. Zajednička karakteristika koja povezuje sve migrante temeljem toga kriterija, a čije ćemo odgovore prikupljene intervjuima na temu povratnih umirovlje- 
ničkih migracija na hrvatskim otocima analizirati u raspravi u ovom radu, jesu umirovljenje, životne promjene i otoci s kojih su emigrirali.

\section{POVRATNE UMIROVLJENIČKE MIGRACIJE}

Za razlikovanje povratnih i umirovljeničkih povratnih migracija postoje argumenti koji dokazuju da povratnici u radno aktivnoj dobi za razliku od umirovljenih uglavnom ostaju aktivni na tržištu rada (Klinthäll, 2006). Značajni dio literature o povratnim migracijama među umirovljenicima bavi se međunarodnim povratnim tokovima nekadašnjih radnih migranata (Cerase, 1974; Bolzman, Fibbi i Vial, 2006; Klinthäll, 2006). Prije razvoja fenomena međunarodnih umirovljeničkih migracija potaknutih prije svega potrošačkim motivima i potragom za ugodnošću (King, Warnes i Williams, 2000) objavljen je veći broj istraživanja umirovljeničkih migracija u nacionalnim okvirima (Illés, 2006: 54).

Visoka primanja kroz zarađene mirovine i niži troškovi života u zemlji/ regiji njihova podrijetla mogu otvoriti mogućnost da stariji (radnici) migranti donesu odluku o povratku. Neke okolnosti povezane s povlačenjem pojedinaca s tržišta rada, poput prijelaza s plaće kao prihoda na mirovinu, što slabi povezanost prebivališta i prihoda, upućuju na mogućnost povećane sklonosti povratku. Donošenje odluke o povratnoj migraciji u vrijeme umirovljenja može pokazati je li riječ o planiranoj strategiji. Utvrđeno je da se prilikom postizanja zakonske dobi za umirovljenje vjerojatnost povratne migracije povećava, posebno za muškarce. Učinak umirovljenja trenutačan je i vjerojatnost za povratnu migraciju u kasnijoj dobi u mirovini naglo pada. Nadalje, i migranti koji se odluče na prijevremenu mirovinu imaju znatno veću vjerojatnost povratne migracije u odnosu na one koji nisu u mirovini. Te vidljive "posljedice umirovljenja« potvrđuju da povratna migracija može biti važna opcija u mogućim strategijama umirovljenja (Klinthäll, 2006). Neki autori naglašavaju važnost sindroma »ispražnjenoga gnijezda«, odnosno odlaska odrasle djece iz roditeljskog doma, i hijerarhijski ga, kao mogući pokretač odluke o migraciji, stavljaju ispred umirovljenja (Plane i Jurjevich, 2009: 12).

U nastojanju da migracijske obrasce stave u kontekst razvojne perspektive životnog toka, Eugen Litwak i Charles Longino (1987) identificirali su tri etape u mobilnosti starijih osoba. Prva je povezana s odlaskom u mirovinu, koja omogućuje pojedincima da se presele jer više nemaju potrebe za životom u blizini mjesta zaposlenja. Ta etapa u životnoj tranziciji osobe jest razdoblje kada postoji veća vjerojatnost za povratnu migraciju. Druga eta- 
pa potaknuta je narušenim zdravljem ili kroničnom bolešću koja utječe na samostalnost pojedinca. Ona može biti povezana i s narušavanjem zdravlja ili sa smrću partnera, pa potiče preseljenje pojedinca k članovima obitelji zbog dobivanja potrebne podrške ili povratnu migraciju. Treća etapa nastaje kada pojedinčeve potrebe može ispuniti samo obitelj ili specijalizirane ustanove.

Ruralno-urbane migracije u ranim fazama industrijalizacije omogućile su stvaranje prvih generacija urbanih stanovnika sa snažnim vezama s regijama podrijetla. S prvim generacijama urbanih stanovnika, koje su nakon institucionalizacije umirovljenja stekle siguran financijski izvor za kasnije životno razdoblje, povezana je urbano-ruralna povratna migracija u mjesta rođenja ili u mjesta u kojima su proveli djetinjstvo (Wiseman, 1980; King, Warnes i Williams, 2000). Ta etapa u razvoju umirovljeničke migracije nije jednoznačna za svaku državu i među njima postoje velike razlike. U Hrvatskoj je primjerice razdoblje industrijalizacije i masovnog napuštanja sela počelo nakon Drugoga svjetskog rata. Nakon umirovljenja se dio osoba koje su provele više desetljeća u radnom odnosu u drugim dijelovima države ili inozemstvu, odlučuje na povratak u mjesta rođenja ili djetinjstva. U daljnjem tekstu referirat ćemo se na citate iz istraživanja o temi ovog rada. Tako je $u$ istraživanju provedenom na Lošinju u intervjuu ekspert potvrdio:

Na Iloviku imate ovih povratnika iz Amerike koji su stalno tu jer su sada u penziji, na Susku isto, ovdje na Lošinju isto. (E, Ž, 63, Lošinj)

Saša Božić o povratnim umirovljeničkim migracijama piše: »Taj oblik umirovljeničke migracije $\mathrm{u}$ internacionalnom kontekstu i danas je aktualan, pogotovo u južnoeuropskim zemljama (među njima i Hrvatskoj) koje su donedavno imale ili još imaju veliku radnu emigraciju« (2001: 315). U kasnijim razvojnim etapama umirovljeničkih migracija veze s mjestom rođenja ili djetinjstva prestaju biti odlučujućim čimbenikom u izboru lokacije za umirovljenje. Prema nekim rezultatima istraživanja povratnih migracija, povratnike u umirovljeničkoj dobi privlače ista mjesta i regije s određenim kvalitetama, poput atraktivnosti krajolika, ruralne očuvanosti, naročito u obalnim područjima, klime, mira i dr., kao i ostale migrante podrijetlom iz drugih područja (Newbold, 1997). Više istraživanja potvrdilo je da će stariji migranti za preseljenje vjerojatnije izabrati ruralna odredišta (Friedrich i Warnes, 2000; Plane i Jurjevich, 2009). Ta sklonost ruralnim odredištima može biti rezultat želje za povratkom u mjesto podrijetla, emocionalnih ra- 
zloga, nostalgije, ali isto tako može biti vođena razlozima više razine ugodnosti. Kako ćemo vidjeti iz rezultata istraživanja predstavljenih u drugom dijelu rada, za povratne umirovljeničke migracije u hrvatskom kontekstu lokalna otočna zajednica još je uvijek važan identitetski resurs i među više istaknutih čimbenika važan je razlog povratka migranata.

U kontekstu preciznije definicije teme ovog rada pojmom povratne umirovljeničke migracije obuhvaćeni su svi vanjski i unutarnji migranti koji se nakon završetka radnog razdoblja vraćaju u mjesta iz kojih su se iselili. Povratne migracije donekle mogu ublažiti dugotrajne negativne demografske trendove i ekonomsko propadanje otoka, ovisno o dobi povratnika i financijskom i društvenom kapitalu koji donose (Podgorelec, 2010: 148). Istraživanja na pojedinim kvarnerskim (Sokolić, 1994), zadarskim (Klempić i Podgorelec, 2002; Podgorelec, 2008) i šibenskim otocima (Podgorelec i Klempić Bogadi, 2013) ustanovila su da se dio umirovljenih otočana odlučuje na povratak po završetku radnog razdoblja. Povratnici mogu biti dočekani s dobrodošlicom jer donose prihode, nove vještine i znanja, no često se u praksi događa da se teško prilagođavaju administrativnim uvjetima i birokratskim zaprekama koje ne postoje u zemljama u kojima su proveli radni vijek. ${ }^{4}$ Također, život u istoj državi, ali u drugim regijama može rezultirati konstrukcijama i promjenama identiteta i načina života koji su nekad u suprotnostima s tradicionalnim praksama lokalnih zajednica iz kojih se krenulo u migraciju. Povratnici imaju neku drugu sliku o mjestu podrijetla, najčešće idealiziranu, pa je i to jedan od razloga što proces reintegracije nije uvijek lagan ni nekonfliktan (Čapo, 2010).

\section{OTOK KAO SIMBOLIČKI RESURS}

Fizičke granice snažno utječu na definiranje društvenih granica. Prostor, prema Georgu Simmelu (1997), ima sociološko značenje jer utječe na udruživanje pojedinaca, odnosno koncept prostora iznimno je važan u svim međuljudskim odnosima. U njemu se ostvaruje interakcija, ali prostor može predstavljati i ograničenja (npr. političke i prirodne granice) te postavljati neke preduvjete za njih. »Granica nije prostorna činjenica sa sociološkim posljedicama, nego se sociološke činjenice formiraju prostorno« (Simmel, 1997: 143). Za zajednice na kopnu granice su imaginarne linije na tlu koje mogu biti predmetom sudskih, vojnih ili političkih prijepora. Za otočane su

4 Ivo Mikulčin, povratnik na Žirju: »Ovdje je sve skuplje i teže nego u Americi«, Slobodna Dalmacija, 1. 10. 2008., http://www.slobodnadalmacija.hr/\%C5\%A0ibenik/tabid/74/articleType/ArticleView/articleId/24455/Default.aspx (11. 07. 2013.). 
one objektivno, prirodno dane činjenice. Simmel nastoji ublažiti distinkciju otočne i kopnene omeđenosti, u smislu političkih granica, jer se more može »kontrolirati« (Simmel, 1997: 141). Prirodnu danost granica znanstvenici smatraju prednošću u istraživanjima jer otoci »funkcioniraju kao mali prostorni laboratoriji gdje se teorije mogu provjeravati i procesi promatrati $u$ ambijentu poluzatvorenih sustava« (King, 1993: 14).

Tragajući za sadržajnijim opisom pojmova otoka, otočnosti i otočnog identiteta, nerijetko nailazimo na romantičarski, idealizirajući pristup otocima i njihovim stanovnicima. Otoci nisu samo »prirodni laboratorij« za prirodnoznanstvena istraživanja (Šimunović, 1994: 452). Otočanima su otoci mnogo više. Otoci su minijaturni svjetovi, male intimne zajednice sa snažnim osjećajem zajedništva. Zajednica daje svojim pripadnicima uloge, režim obveza, reciprocitet u odnosima i bliskost. Pripadanje zajednici pretpostavlja posjedovanje potrebnih znanja, tradiciju, društveni kapital, mreže, ali i antimreže, često artikulirane putem vlastitog jezika ili dijalekta, kao i vlastiti osjećaj prostora i vremena (Baldacchino, 2005: 248). Otočno stanovništvo Hrvatske pod snažnim je utjecajem fizičke ograničenosti prostora i položaja koji je manje ili više izoliran u odnosu na kopno. Ti su čimbenici utjecali na mnoge segmente života otočnog stanovništva, što otoke čini, osim fizičkih, i specifičnim društvenim prostorima.

Nemogućnost osiguravanja egzistencije na otoku navodi se često u raznim istraživanjima (Sokolić, 1994; Klempić i Podgorelec, 2002; Babić, Lajić i Podgorelec, 2004; Podgorelec, 2008, 2010; Faričić, Graovac i Čuka, 2010; Podgorelec i Klempić Bogadi, 2013) kao jedan od primarnih potisnih čimbenika za iseljavanje. Tako se i u provedenom istraživanju na šibenskim otocima i Lošinju ispitanici prisjećaju teških životnih uvjeta koji su ih poticali na iseljavanje, ali koji i danas potiču mlade otočane na iseljavanje.

Mladost je išla, i ja san. Radili smo u gradu [Šibeniku, op. a.], kuću smo napravili. Ode mladost ne može živit ni radit. Ima ih [iseljenih Žirjana, op. a.] vani u Zagrebu, po Šibeniku, ima u Dubrovniku, u Zadru (...) dojdu priko lita u sezoni. Kad odu, teška tišina. Ode se nije rodilo dite malo, sad će 35 godina kad se zadnje dite rodilo na ovom otoku. Ne kopamo Polje ${ }^{5}$, ne radimo, mladost neće, stari ne mogu. (Ž, 74, Žirje)

5 Na središnjem dijelu otoka Žirja nalazi se prostrano i plodno Polje. Umirovljeni otočani i stanovnici podrijetlom s otoka koji većinu vremena žive u Šibeniku ili drugim naseljima na obali, obrađuju samo dio Polja te maslinike najbliže naselju. Na otoku je zamro i uzgoj stoke (Faričić i Magaš, 2004: 137). 
Iako su ih teški životni uvjeti poticali na emigraciju, ispitanici se nostalgično prisjećaju vremena kada su otočne zajednice živjele skromno, ali su bile brojnije i provodile vrijeme $u$ raznim oblicima društvene interakcije (npr. radu i druženju). Čimbenici koji su otočane u mladosti poticali na iseljavanje (primjerice ruralnost prostora, nerazvijenost) $u$ kasnijoj životnoj dobi mogu postati privlačni i utjecati na odluku o povratku.

Kad sam bila mlada, pivala sam po cile dane i noći, na ribe kad smo išli, od kuće bi pivali do pošte $e^{6}$ od pošte do doma. Žene su ribarile više nego muški. Muški su cijenili ženu i žene muške. Fino je bilo. Bila sam od najboljih ribarica u Dalmaciji. Ja sam i mriže krpala i ulje u motoru prominila. Prije smo i na vesla išli. Bilo je dobro. (̌̌, 91, Kaprije)

Fizičko preseljenje u drugu sredinu ne mora nužno značiti da se osoba preseljava i emocionalno. U provedenom istraživanju često su navođeni razlozi povratka emotivni odnos prema otoku i nostalgija. Emocionalna povezanost nikada nije bila prekinuta, a boravak izvan otoka ispitanici otočani često smatraju samo jednom od etapa svoga života zbog imperativa zaposlenja, vlastitog školovanja ili školovanja djece:

Nije bilo lako, odlučili smo potražiti sriću u Americi i tamo smo ostali trideset godina. Tamo su nam ostala dica i unuci. Na Kapriju nam je bolje nego u Americi. (M, 84, Kaprije)

Žirje je raj na zemlji. Nema lipšeg od mog škoja. (Ž, 74, Žirje)

Nikad ne bih otišao s otoka da sam ovdje mogao naći posao. Nisam imao dileme oko toga hoću li se vratiti u mirovini. Ovaj mir koji tu imam i prijatelje, tko to može platiti? (M, 76, Zlarin)

Radio sam u Zagrebu do 2010., kad sam otišao u prijevremenu mirovinu. Ne mogu reći da mi je bilo loše u Zagrebu, ali s godinama me je sve više vuklo natrag. (M, 59, Lošinj)

Povratnicima puno znači intima otočnog života. Posebice je to slučaj s malim otocima, na kojima postoji čvrsti osjećaj zajedništva, ali i svijest o demografskoj ugroženosti zajednice:

Ribolovna mjesta. 
Na otoku je lipo, mirno, čisto i svi se pazimo. Samo zimi ne valja. Ostane nas oko Božića i Nove godine samo šačica koji smo stalno tu. I to je sve stari svit osamdeset $i$ više godina i svaki dan nas je sve manje. (Ž, 74, Žirje)

Statističkim podacima ne može se sa sigurnošću utvrditi koliko je stanovnika registrirajući stalno mjesto boravka u nekom od otočnih naselja svoj »drugi dom « uistinu pretvorilo $\mathrm{u}$ »prvi«, a koliko ih je to učinilo fiktivno zbog izbjegavanja financijskih obaveza prema lokalnoj zajednici (Mišetić, 2006: 98). Tako se nerijetko događa da »otoci na rubu biološkog izumiranja daju statistički privid demografske ekspanzije, pa tek posredne analize govore o pravom otočkom stanju « (Lajić i Mišetić, 2005: 215). Promatra li se registrirano stanovništvo kao stvarno, može se zaključiti da otoci postaju rezidencijalno odredište starije populacije (Mišetić, 2006: 110). Ta je pojava učestala na pojedinim manjim otocima bližim kopnu te dijelovima većih otoka, a česta je i praksa sezonskog boravka na otocima. Brojni empirijski slučajevi pokazuju da granica između stanovanja na jednoj ili više adresa ni hijerarhija između različitih adresa nisu uvijek najjasnije ni lako odredive. Za dodatnu nedorečenost krive su administrativne prakse, koje ne dopuštaju mogućnost da pojedinac ravnopravno živi na dva ili više mjesta. Na hrvatskim otocima, napose onima malima i udaljenima od obalnih središta, nije rijedak slučaj boravka izvan otoka u zimskim mjesecima:

Imam dvi sestre, stare isto, na otoku. Samo, one žive zimi u gradu. Oden mi je sin i kći na otoku, a imaju kuće u gradu. (Ž, 91, Kaprije)

Kao razloge odluke o bilokalnom načinu stanovanja ispitanici navode nepovoljne vremenske uvjete u zimskim mjesecima, mogućnost prekida brodskih linija, zdravstvene poteškoće, nepostojanje adekvatne zdravstvene usluge na otocima i sl. Naime otoci su tijekom zimskih mjeseci slabije povezani s kopnom, što rezultira rjeđim posjetima članova obitelji koji žive izvan otoka, a nerijetko su glavni opskrbljivači otočnih stanovnika namirnicama, lijekovima i drugim potrepštinama. To je često razlog provođenja zimskog razdoblja izvan otočnog doma. ${ }^{7}$

Mnogi iseljeni otočani naslijedili su roditeljske kuće, obnavljali ih i održavali ili su sagradili nove obiteljske kuće, koje su važna spona za povratnu migraciju:

I izvan zimskih mjeseci otočani su u nabavi prehrambenih artikala usmjereni na grad zbog znatnih razlika u cijenama i izboru artikala: »Svi idu u grad kupovati jer je jeftinije.« (M, 76, Zlarin) 
Naslijedio sam roditeljsku kuću, koju sam renovirao. (M, 59, Lošinj)

Kuća ima puno godina, ima više od stotinu godina. Prije je to bio stari magazin. Svaki je u svojoj sobi i ovi što tu rades. Ja sam sama u svojoj sobi. Mi malo koji da nemamo kuće u gradu i ovdi. Mi smo po dvi kuće gradili u socijalizmu. Jednu u Kaprij svaki je imao, a drugu u Šibenik svaki. (Ž, 91, Kaprije)

Muž je naslijedio komad zemlje i na okućnici roditeljske kuće smo napravili novu. Imamo $i$ stan u Šibeniku, tamo nam je sin. (Ž, 64, Zlarin)

Jedan od razloga povratka na otok, uz završetak radnog razdoblja, jest potreba da se djeci koja ostaju u gradovima izvan otoka prepusti stan i riješi njihovo stambeno pitanje (Klempić i Podgorelec, 2002: 332; Podgorelec i Klempić Bogadi, 2013: 46-47). Bilocirana obitelj, kao specifično obilježje migranata, može biti važna motivacijska pozadina povratka (Peračković, 2006: 487). Iako je češći slučaj da se roditelji u nekom životnom razdoblju, najčešće zbog narušenog zdravlja i kroničnih bolesti, presele djeci, manji broj »mlađih « umirovljenika vraća se na otoke zbog roditelja u dubokoj starosti koji trebaju pomoć u svakodnevnom životu. Tako ispitanica na Kaprijama kaže:

Sin i kći su mi tu, oboje su u mirovini. Uvik je tu neko uz mene. (Ž, 91, Kaprije)

Otočne su zajednice zbog brojnih valova i smjerova migracija postale $\mathrm{u}$ nekim segmentima transnacionalne. Tradicijska kultura postupno se mijenja, modernizira i globalizira. »Ipak, otok ostaje čvrsta točka materijalnih i simboličkih odnosa, pa otočani, i oni u iseljeništvu, zadržavaju snažni osjećaj pripadanja određenom otoku. Posebice je to slučaj s malim otocima, s njihovim relativno homogenim i intimnim društvima u kojima postoji čvrsti osjećaj zajedništva« (Podgorelec i Klempić Bogadi, 2013: 90).

Na osnovi dosadašnjih istraživanja (Sokolić, 1994; Klempić i Podgorelec, 2002; Babić, Lajić i Podgorelec, 2004; Podgorelec, 2008; Podgorelec i Klempić Bogadi, 2013) i istraživanja provedenog za potrebe ovog rada povratnike umirovljenike možemo podijeliti na one iz inozemstva (prekooceanske zemlje, europske zemlje, povratnici nekadašnji optanti - uglavnom na cresko-lošinjskom otočju ${ }^{9}$ ), povratnike iz kopnenih dijelova Hrvatske i povrat-

8 Ispitanica misli na sezonske radnike koji rade u ugostiteljstvu.

9 Prema riječima ekspertice na Lošinju: »Ima nekadašnjih optanata koji su se odlučili vratiti.

Nije masovna pojava, ali toga ima. Stariji mještani ih priznaju svojima.« (E, Ž, Lošinj) 
nike s drugih otoka. Kao posebna skupina izdvajaju se iseljenici cirkulanti koji redovito dolaze na otok, u posjet roditeljima, rodbini ili prijateljima, a u razdoblju mirovine borave na otocima bez nekog određenog ritma i hijerarhije između doma na kopnu i otoku.

\section{REINTEGRACIJA U OTOČNU ZAJEDNICU}

U malim zajednicama, poput otočnih, prilično su jasne granice koje dijele pripadnike i nepripadnike ili strance. Na distinktivnu lokalnu kulturu i otočnost gleda se s poštovanjem, a autohtonost i višegeneracijska prisutnost temelj su za pristup vodećim pozicijama u zajednici (Marshall, 1999). U ekspertnom intervju provedenom na otoku Lošinju sugovornica tako ističe važnost zavičajnosti na otoku za otočni identitet, odnosno stupnja pripadanja zajednici:

Tradiciju po rođenju po nekakvim prezimenima, to je jasno neko ko je tu tristo godina, ali ima i nekih ljudi koji su dolazili tu za vrijeme Austro-Ugarske pa su se ženili s lokalnim ženama $i$ isto manje-više ispada da su nekakvi Lošinjani. (E, Ž, 63, Lošinj)

Iseljeni otočani i članovi njihovih obitelji, iako nisu stalni stanovnici, smatraju se dijelom otočne zajednice. Aktivnim participiranjem u otočnoj kulturi i načinu života kroz posjete te sudjelovanjem u kulturnim manifestacijama, zajedničkom radu, obiteljskim okupljanjima i sl. premošćuju fizičku odvojenost i zadržavaju osjećaj pripadanja određenom otoku. Sugovornik s otoka Zlarina svjedoči o brojnim poveznicama s otokom tijekom svoga života na kopnu:

Uvijek je bilo razloga za biti na otoku. Trebalo je raditi u polju oko maslina, loze (...) pa kad se familija okupi. (M, 76, Zlarin)

Posjeti rodbine i prijatelja podjednako su važni i otočanima koji su na otoku stalno naseljeni:

To je osjećaj ugrožene vrste da nestajemo. Upravo zato što su nakon Drugog svjetskog rata došli drugi, ali onaj nukleus koji još uvijek je tu negdje recimo u bližim državama ili daleko u Americi ili Australiji i koji preko ljeta dolaze, i onda ti je nekako ono milo što su došli osjećaš oh [usklik, op. a.], tu sam kod kuće još 
uvijek. Onda kad oni odu, osjećaš neku prazninu i misliš (...) to je ta sad moja generacija koja ima možda mojih godina, recimo malo stariji, pitanje je hoće li njihovi unuci dolaziti ovamo. (E, Ž, 63, Lošinj)

Iz sugovorničinih riječi možemo zaključiti da otočani iskazuju strah da zajednica postupno slabi te da mlade generacije više nisu jednako povezane s otočnom zajednicom. Odluke o povratku na otok najčešće se temelje na iskustvima boravka i sudjelovanja $u$ aktivnostima otočne zajednice. Tijekom radnog razdoblja mnogi su iseljeni otočani nastojali što češće boraviti na otoku tijekom praznika i godišnjih odmora. Iseljenici u bližim obalnim gradovima nastojali su posjećivati otok svaki vikend, najčešće zbog roditelja koji su na njemu ostali živjeti:

Muž je bio oficir, pa smo svi bili u Dubrovniku, ali smo često dolazili. (̌̌, 91, Kaprije)

Posjećivali smo roditelje ljeti za godišnjih odmora i kad god smo mogli. Sada nas tako posjećuju djeca i unuci. Kad nisu s nama, čujemo se svi telefonski i djeca $i$ unuci. (Ž, 65, Lošinj)

Male zajednice poput otočnih imaju jaču socijalnu kontrolu, stupanj intimnosti članova zajednice izražen je, čvrsti su međusobna povezanost i povjerenje. Većina ispitanika ističe razvijeni osjećaj zajedništva i prihvaćenosti u lokalnoj zajednici:

Svaki se lipo javi meni, ja njemu, bilo muško, bilo žensko. Meni se ljudi dobro ophode, onda je dobro meni, dobro je i njima. Niki nije proša da mi se nije javio. (Ž, 91, Kaprije)

Znamo jedan drugog, to je važno. Pozna se drugi narod koji dođe. (M, 77, Žirje)

Među povratnicima koji se teže integriraju najčešće su otočani koji su život proveli kao iseljenici u prekooceanskim zemljama (Podgorelec i Klempić Bogadi, 2013: 93). Kako pokazuje navedeno istraživanje (Podgorelec i Klempić Bogadi, 2013), a potvrdilo se i u istraživanju provedenom na tri šibenska otoka i Lošinju, najčešće je riječ o pojedinačnim slučajevima. Sugovornik s Kaprija tako ističe nezadovoljstvo administracijom: 
Svima su puna usta otoka, a ništa se ne radi da se svit vrati. Ni nama starima da se skrasimo na svom škoju. Ako nešto hoćete napraviti, sve vam se višestruko naplati. Znači, žele vas pokrasti. (M, 84, Kaprije)

Odlaskom iz svoje sredine iseljenici zadržavaju idealizirano sjećanje na otok kakav je bio u njihovoj mladosti. Dugo izbivanje i nesudjelovanje u životu zajednice mogu utjecati na gubitak kruga ljudi iz mladosti te na percepciju životnih uvjeta i životnih praksi karakterističnih za otok. Reintegraciju možemo nazvati »dugim putem kući« jer se nakon fizičkog povratka povratnici moraju i »društveno vratiti«. Društveni odnosi na otoku nisu jednaki tijekom cijele godine, o čemu svjedoči sugovornik s Lošinja:

Život na otoku je posebna priča. Lošinj je veliki otok, ima puno stanovnika, to je već grad, ali kad dođe zima, prvi-drugi mjesec (...) do Božića i Nove godine još ide, ali onda je malo problematično. Ljudi su (...) već su se novci potrošili koji su se od sezone uštedjeli, onda se povlače svi u sebe, dođe tu do nekakvih i razmirica medusobnih, neko se posvada, neko ne vidi nekog tjedan dana, pa misli da se uvrijedio, pa se onda i on uvrijedi bez razloga. Život na otoku, to je posebna filozofija. Manji otoci su još gori. Susak, Unije, Ilovik, tamo je po zimi svi protiv svakog, svaki protiv svih $i$ svi protiv svakog, to je priča za sebe. Ali opet su zajednica $i$ opet se skupe $i$ kad nekom treba pomoći, svi će mu pomoći. Takva je životna filozofija. (M, 59, Lošinj)

Povratnici umirovljenici zadržavaju veze s prostorom i zajednicama u kojima su prethodno boravili, pa se periodično vraćaju na kraća ili duža razdoblja u izvanotočne sredine zbog obiteljskih i drugih veza. Osjećaj neprihvaćenosti povratnika u zajednici utoliko je snažniji ukoliko se kvaliteta društvenih odnosa razlikuje od njihovih očekivanja. Do nesporazumâ dolazi zbog načina na koji povratnici uređuju svoje kuće (razlike u stilu tradicionalne i moderne arhitekture $)^{10}$ te nastojanja da se uvedu inovacije kojima se lokalna zajednica protivi. ${ }^{11}$ Povratnici se gotovo u pravilu vraćaju iz razvijenijih urbanih sredina, nerijetko i inozemnih, te je neizbježno miješanje životnih stilova. Riječ je o skupini koja je integrirala razna životna iskustva i identitete: one od lokalne otočne zajednice, migrantsko iskustvo,

10 Neki povratnici na otocima nastoje promovirati vlastitu uspješnost preko kuća, koje u nekim slučajevima bojama, ukrasnim elementima i načinom gradnje odudaraju od tradicionalnih otočnih kuća.

11 Jedan od primjera jest neuspješni pokušaj pokretanja spalionice smeća na otoku Zlarinu. 
nove društvene vrijednosti te različita radna i profesionalna iskustva, pa stvara identitetsko uporište $u$ dvije zajednice ili više njih. Razlike su najočitije u nedostatku nekih sadržaja i praksi na koje su navikli u kopnenim središtima. ${ }^{12} \mathrm{~S}$ druge strane, povratnici donose i inovacije, nove tehnologije i sredstva koje sredina prihvaća. ${ }^{13}$ Istovremeno postoji snažan osjećaj da su povratnici dobrodošli, napose u slučajevima gdje su rodbinske i prijateljske veze sačuvane. Tako sugovornica zaključuje:

Oni jesu integrirani $i$ dio otoka $i$ mještani ih priznaju svojima, samo su bili na radu vani $i$ sad su se vratili, ništa drugo. (E, Ž, 63, Lošinj)

Uz povratnike se prihvaćaju i doseljenici koji nemaju otočno podrijetlo jer sa sobom nose sve ono čega na otocima danas ima sve manje ili posve nedostaje: društveni i gospodarski kapital, nove vještine i znanja. Tako su ispitanici iskazivali visoki stupanj svijesti o demografskoj ugroženosti svojih zajednica i želju da one opstanu. Veći broj stanovnika na otoku za stanovništvo znači zadržavanje postojeće infrastrukture (javne službe, prometna povezanost, zdravstvena skrb) i stvaranje novih vrsta infrastrukture, a sve zajedno bolju kvalitetu života.

\section{POVRATAK KAO KONAČNI ČIN?}

Povratna migracija u kasnijoj životnoj dobi, prema modelu koji su razvili Litwak i Longino (1987), ne mora biti konačna. Dio povratnika u kasnijoj životnoj dobi sudjeluje u reverzibilnom procesu i ponovnom seljenju (drugom povratku) u sredinu gdje su osobe provele radnu dob ili bliže članovima obitelji, odnosno u sredinu s boljom zdravstvenom i socijalnom skrbi za starije. Potisni čimbenici tog procesa mogu biti smrt partnera, narušeno zdravlje, kronična bolest, financijske poteškoće i nesamostalnost pojedinca. Od četiri otoka uključena $u$ istraživanje dom za starije i nemoćne postoji samo na Lošinju. Šibenski otoci nemaju specijaliziranih ustanova koje bi se brinule o starijim osobama. U domu za starije i nemoćne Cvjetni dom u Šibeniku od ukupnog broja korisnika oko deset posto čine nekadašnji sta-

12 »Život na otoku je skup. Kad nešto zatreba, dvaput promislim gdje i kad kupiti. Osnovne namirnice više nisu toliko skupe od kada su se otvorili novi trgovački lanci u gradu.« (M, 59, Lošinj)

13 Primjerice na nekim hrvatskim otocima poput Zlarina i Kaprija zabranjen je promet automobilima. Povratnici su uveli ekološki prihvatljiva i ekonomična "golf-vozila" na električni pogon, koja su podjednako prihvatili i mještani i doseljenici na otocima. 
novnici šibenskih otoka. Za starije osobe na otocima, najčešće u samačkim kućanstvima, u visokoj starosnoj dobi, bez djece ili s djecom odseljenom s otoka, brinu se gerontodomaćice, koje nisu educirane za pružanje osnovne zdravstvene skrbi, ali pomažu pri dostavi namirnica i lijekova, kućanskim poslovima, odlasku liječniku i sl. Istraživanja provedena na hrvatskim otocima u posljednjih desetak godina (Lajić, Podgorelec i Babić, 2001; Babić, Lajić i Podgorelec, 2004; Podgorelec, 2008; Podgorelec i Klempić Bogadi, 2013) potvrdila su da se većina otočana zalaže za otvaranje doma na svojim otocima, ali pritom u velikoj većini odbijaju mogućnost da i sami jednog dana budu smješteni u instituciju. Naime mogućnost da djeca otočana koji žive u blizini otoka (npr. u Šibeniku) dopuste da se za njih brinu institucije, a ne oni sami, još se uvijek smatra sramotom. Iskazanu želju za samostalnim životom na prostoru otoka i odbijanje ideje o preseljenju na kopno potvrđuju riječi ispitanice s Kaprija:

Sad kad sam ostarila, sad ne mogu nigdi, nigdi, nego ovako sidi i stoj. A di bi išla? (Ž, 82, Kaprije)

\section{ZAKLJUČAK}

Otoci su svojim iseljenim i stalnim stanovnicima simbolički resurs identiteta i okupljaju ih oko ideje očuvanja otočne tradicije. Veze s domovinom i/ili mjestom podrijetla, čak i ako su slabijeg intenziteta, održavaju težnju za povratkom. Povratak je dugotrajan, složen proces koji s jedne strane sadržava elemente romantičarskog pristupa i nostalgiju za vremenom, prostorom i ljudima kakvi su nekada bili, a s druge procjenu onoga što povratak uistinu nudi. Najveći broj iseljenih otočana odlučuje se za povratak na otok podrijetla odmah nakon umirovljenja. Svojim povratkom značajno povećavaju broj starijih u ukupnoj otočnoj populaciji i samo prividno demografski revitaliziraju lokalne zajednice. Mnogi su od njih tijekom cijelog razdoblja života izvan otoka planirali povratak i obavljali određene pripreme kako bi na otoku mogli provesti mirovinu. Riječ je većinom o otočanima koji na rodnome otoku posjeduju nekretninu, naslijeđenu roditeljsku kuću ili novu obiteljsku kuću koju su sagradili tijekom radnog vijeka, koja je važni preduvjet za stalnu ili sezonsku povratnu migraciju.

Reintegracija $\mathrm{u}$ otočnu zajednicu, u koju se povratnici umirovljenici odlučuju vratiti zbog pretpostavke da će biti dobro prihvaćeni, trebala bi biti lagan i nekonfliktan proces. To se napose odnosi na otočane koji su 
radni vijek proveli u bližim obalnim središtima kojima stanovništvo pojedinih otoka gravitira i održavali trajnu povezanost s otočnom kulturom i otočnim načinom života kroz česte posjete otoku. Povratnici umirovljenici iz inozemstva mogu naići na probleme u procesu reintegracije (zbog duljine boravka izvan otoka, rjeđih posjeta i gubitka društvenih veza), ali i administrativnih praksi, koje se u sredini u koju se vraćaju i pokušavaju integrirati značajno razlikuju od onih u zemljama u kojima su proveli radni vijek. Iako postoje pojedini primjeri poteškoća u reintegraciji, čini se da prevladava snažan osjećaj pripadanja i bliskosti, posebno u malim otočnim zajednicama. Za veći broj umirovljenika može se reći da prakticiraju sezonsku povratnu migraciju - boravak tijekom većeg dijela godine na otoku, a u zimskim mjesecima uglavnom u gradovima kod članova obitelji.

\section{LITERATURA}

Atchley, R. C. (1976). The Sociology of Retirement. Cambridge: Shenkman Publishing Company.

Babić, D., Lajić. I. i Podgorelec, S. (2004). Otoci dviju generacija. Zagreb: Institut za migracije i narodnosti.

Baldacchino, G. (2005). Editorial: Islands - Objects of Representation, Geografiska Annaler. Series B, 87 (4): 247-251, doi: 10.1111/j.0435-3684.2005.00196.x

Bolzman, C., Fibbi, R. i Vial, M. (2006). What To Do After Retirement? Elderly Migrants and the Question of Return, Journal of Ethnic and Migration Studies, 32 (8): 1359-1375, doi: 10.1080/13691830600928748

Božić, S. (2001). Posljednja avantura: umirovljeničke migracije, klima i »ugodnosti«, Migracijske i etničke teme, 17 (4): 31-46.

Cerase, F. (1974). Expectations and Reality: A Case Study of Return Migration from the United States to Southern Italy, International Migration Review, 8 (2): 245-262, doi: $10.2307 / 3002783$.

Costa, D. (1998). The Evolution of Retirement: An American Economic History, 1880-1990. Massachusetts: National Bureau of Economic Research.

Čapo, J. (2010). Različiti pristupi povratnim migracijama: primjer Hrvatske, Studia ethnologica Croatica, 22 (1): 11-38.

Dumont, J. C. i Spielvogel, G. (2008). Return Migration: A New Perspective, u: International Migration Outlook 2008. Paris: OECD, 161-222, doi:10.1787/migr_outlook-2008-en.

Evandrou, M., Falkingham, J. i Green, M. (2010). Migration in later life: evidence from the British Household Panel Study, Population Trends, 141: 77-94, doi: 10.1057/pt.2010.22.

Faričić, J. i Magaš, D. (2004). Suvremeni socio-geografski problemi malih hrvatskih otoka - primjer otoka Žirja, Geoadria, 9 (2): 125-158.

Faričić, J., Graovac, V. i Čuka, A. (2010). Mali hrvatski otoci - radno-rezidencijalni prostor i/ili prostor odmora i rekreacije, Geoadria, 15 (1): 145-185. 
Friedrich, K. i Warnes, A. M. (2000). Understanding Contrasts in Later Life Migration Patterns: Germany, Britain and the United States, Erdkunde, 54 (2): 108-120, doi: 10.3112/erdkunde.2000.02.02.

Haas, W. H., Bradley, D. E., Longino Jr., C. F., Stoller, E. P. i Serow, W. J. (2006). In retirement migration, who counts? A methodological question with economic policy implications, The Gerontologist, 46 (6): 815-820, doi:10.1093/geront/46.6.815.

Hooyman, N. R. i Kiyak, H. A. (2008). Social Gerontology: A Multidisciplinary Approach. Boston: Pearson Education.

Illés, S. (2006). International Elderly Migration in Hungary, Migracijske i etničke teme, 22 (1-2): 53-77.

King, R. (1986). Return Migration and Regional Economic Development: an Overview, u: R. King (ur.). Return Migration and Regional Economic Problems. London: Croom Helm, 1-37.

King, R. (1993). The Geographical Fascination of Islands, u: D. G. Lockhart, D. DrakakisSmith i J. Schembri (ur.). The Development Process in Small Island States. London - New York: Routledge, 13-37.

King, R., Warnes, T. i Williams, A. (2000). Sunset Lives: British Retirement Migration to the Mediterranean. Oxford - New York: Berg.

Klempić, S. i Podgorelec, S. (2002). Migracije i starenje otočnog stanovništva - pet iških priča, Migracijske i etničke teme, 18 (4): 319-338.

Klinthäll, M. (2006). Retirement Return Migration from Sweden, International Migration, 44 (2): 153-180, doi: 10.1111/j.1468-2435.2006.00367.x.

Lajić, I., Podgorelec, S. i Babić, D. (2001). Otoci-ostati ili otići?: studija o dnevnoj cirkulaciji sa šibenskih otoka. Zagreb: Institut za migracije i narodnosti.

Lajić, I. i Mišetić, R. (2005). Fertilitet, natalitet i ukupno kretanje stanovništva otoka u razdoblju između 1981. i 2001. godine, u: D. Živić, N. Pokos i A. Mišetić (ur.). Stanovništvo Hrvatske - dosadašnji razvoj i perspektive. Zagreb: Institut društvenih znanosti Ivo Pilar, 211-226.

Litwak, E. i Longino, C. (1987). Migration Patterns Among the Elderly: A Developmental Perspective, Gerontologist, 27 (3): 266-272, doi:10.1093/geront/27.3.266.

Mišetić, R. (2006). Neka sociodemografska obilježja stanovništva obalnih naselja, Društvena istraživanja, 15 (1-2): 97-114.

Nejašmić, I. (1981). Povratak jugoslavenskih vanjskih migranata i njihovo uključivanje u gospodarski i društveni život zemlje. Zagreb: Centar za istraživanje migracija.

Newbold, B. K. (1997). Primary, return and onward migration in the U.S. and Canada: is there a difference?, Papers in Regional Science, 76 (2): 175-198, doi: 10.1111/j.14355597.1997.tb00688.x.

Peračković, K. (2006). Sociološki pristup u istraživanju procesa povratnih migracija, Društvena istraživanja, 15 (3): 475-498.

Phillipson, C. (1998). Reconstructing Old Age: New Agendas in Social Theory and Practice. London: Sage.

Plane, D. A. i Jurjevich, J. R. (2009). Ties That No Longer Bind? The Patterns and Repercussions of Age-Articulated Migration, The Professional Geographer, 61 (1): 4-20, doi: 10.1080/00330120802577558.

Podgorelec, S. (2008). Ostarjeti na otoku: kvaliteta života starijega stanovništva hrvatskih otoka. Zagreb: Institut za migracije i narodnosti. 
Podgorelec, S. (2010). Migracija kao sudbina: hrvatski otoci i starenje stanovništva, u: I. Lajić (ur.). Migracije i regionalni razvoj Hrvatske. Zagreb: Institut za migracije i narodnosti, 141-162.

Podgorelec, S. i Klempić Bogadi, S. (2013). Gradovi potopili škoje: promjene u malim otočnim zajednicama. Zagreb: Institut za migracije i narodnosti.

Reyes, B. I. (1997). Dynamics of Immigration: Return Migration to Western Mexico. San Francisco: Public Policy Institute of California.

Seidman, I. (2006). Interviewing as Qualitative Research: A Guide for Researchers in Education and the Social Sciences. 3rd. ed. New York - London: Teachers College, Columbia University.

Simmel, G. (1997). The sociology of space, u: D. Frisby i M. Featherstone (ur.). Simmel on Culture. London: Sage, 137-169.

Sokolić, J. (1994). Otok Susak - mogućnosti revitalizacije, Društvena istraživanja, 4-5 (1213): 503-515.

Szinovacz, M. E. (2003). Contexts and Pathways: Retirement as Institution, Process, and Experience, u: G. A. Adams i T. A. Beehr (ur.). Retirement: Reasons, Processes, and Results. New York: Springer, 6-52.

Šimunović, I. (1994). Otoci u svjetlu socio-ekonomskih kretanja, Društvena istraživanja, 3 (4-5): 451-466.

Williamson, J. i Pampel, F. (1993). Old Age Security in Comparative Perspective. New York: Oxford University Press.

Wiseman, R. F. (1980). Why Older People Move: Theoretical Issues, Research on Aging, 2 (2): 141-154, doi: 10.1177/016402758022003. 


\title{
Return Retirement Migration on Croatian Islands
}

\section{Mario Bara}

\begin{abstract}
SUMMARY
Emigration and depopulation on most Croatian islands is a continuous process lasting for decades which has determined their demographical and socio economic development. For many immigrants returning home is a possibility they think about during their entire lifetime. Although return flows may somewhat mitigate the negative long-term demographic trends, return retirement migration is the prevailing form of return migration to Croatian islands, especially to smaller ones. Consequently, the share of the elderly in the total population number is increasing, thus only masking the real consequences of long-term emigration. This paper addresses three basic concepts: retirement, return migration and reintegration into local island communities. The base are survey data collected by using interview method with returnee pensioners to four Croatian islands (Lošinj, Zlarin, Kaprije i Žirje). Through the life course model, the return is viewed only as one of the stages in the migration process, which does not have to be final but may be potentially reversible step.
\end{abstract}

KEY WORDS: retirement, return migration, reintegration, Croatian islands 